\title{
MORFOMETRICKÁ ANALÝZA A MORFODYNAMICKÉ PROCESY VO VYBRANEJ ČASTI MALEJ FATRY
}

\author{
Veronika Máliková
}

\begin{abstract}
Through its morphometric characteristics, the relief greatly affects the spatial differentiation of the full range of processes, either natural or anthropogenic. Physical and morphometric conditions of a mountain range Mala Fatra predetermine it for the establishment and support of a wide range of morphodynamic processes. The thesis deals with statistical and spatial relief analysis of a selected part of Mala Fatra in order to provide comprehensive information on its characteristics, focusing on selected morphometric parameters and current processes of relief formation that shape this mountain range. The article provides information on the physical and geographical measurements and contains a comprehensive analysis of the dynamics and spatial differentiation of typical for this area morphodynamic processes in the context of the impact of morphometric parameters of relief on their spatial distribution. The article is based on theoretical knowledge of statistical and spatial analysis and on the results of field research. Special consideration is given to the detailed analysis of parts of the Vrátna (valley). The parts of the article are mapping outlets and photo documentation.
\end{abstract}

Keywords: morphometric analysis, morphodynamic processes, Mountain range Malá Fatra, Vrátna dolina valley

\section{Úvod}

Georieliéf je predmetom záujmu človeka $\mathrm{z}$ rôznych hl'adísk a $\mathrm{z}$ mnohých oblastí jeho činnosti. Intenzívne sa skúma v mnohých geovedných disciplínach, avšak najširším hl'adiskom, z ktorého sa reliéf študuje, je hl'adisko geografické. $\mathrm{V}$ ňom sa georeliéf chápe ako súčast' geografickej krajinnej sféry, a preto sa skúma komplexne. $Z$ geografického hl'adiska je georeliéf nielen výslednicou endogénnych a exogénnych síl, ale zároveň sám tieto procesy ovplyvňuje spätne, a to prostredníctvom množiny jeho morfometrických parametrov definovaných v každom l'ubovol'nom bode georeliéfu. Platí to najmä pre procesy spôsobené exogénnymi silami. Preto je georeliéf aj jedným zo základných diferenciačných faktorov v krajine, ktorý sa podiel'a na jej priestorovej diferenciácii do jednotlivých celkov na rôznych hierarchických úrovniach (Krcho, 1990).

Malá Fatra ako zložitý krajinný systém, ktorý sa mení v priestore a čase vytvára najmä svojimi fyzickogeografickými danost’ami podmienky pre rozsiahlu 
priestorovú diferenciáciu reliéfotvorných procesov s rôznym stupňom intenzity a prejavu, ktoré sú determinované morfometrickými vlastnost’ami georeliéfu. V dôsledku tejto súvislosti vznikajú na povrchu zemskej kôry tvary, ktoré sú odrazom vzt'ahu medzi geometrickými a genetickými formami georeliéfu.

Ciel'om príspevku je poskytnút' komplexné informácie o reliéfe vybranej časti Malej Fatry s dôrazom na vybrané morfometrické parametre, ako aj súčasné reliéfotvorné procesy, ktoré toto pohorie formujú, v kontexte vplyvu morfometrických vlastností reliéfu na ich priestorovú diferenciáciu (Hreško, Boltižiar, 2001).

\section{Teoreticko-metodické východiská}

Morfometrické parametre možno vyjadrit' priestorovými mierami, a z nich odvodenými parametrami, ako je výška, dížka, šírka, plocha, skon, krivost' a pod. Používajú sa na charakteristiku zložitej plochy, akou je i georeliéf, popri kvalitatívnych (morfografických) termínoch (Minár, Machová, 2010). Morfodynamické procesy tvoria dynamickú kategóriu, ktorá sa v dôsledku pôsobenia zemskej gravitácie, vnútornej nestability litosféry a zmien odohrávajúcich v tzv. vonkajších geosférach (atmosfére, hydrosfére, biosfére atd'.) podiel'a na neustálych zmenách tvarov zemského povrchu (Lacika, 1997).

Pre získanie a následne spracovanie údajov a vyhodnotenie výsledkov sme použili vybrané metódy a postupy, ktoré sa skladali zo štúdia informačných zdrojov, terénneho výskumu, metódy vysvetl'ujúceho opisu, štatistickomatematickej metódy, kartografickej a systémovej metódy.

Základ tvorila metóda štúdia informačných zdrojov, ktorá sa v prvom rade odrazí na kvalite, teda na obsahovej i štylistickej stránke. Printovú odbornú literatúru sme dopĺn̆ali elektronicky dostupnou literatúrou ako aj mapovými interpretáciami $\mathrm{v}$ analógovej a elektronickej podobe.

Ťažiskom práce bol vlastný terénny výskum, ktorý sme vykonávali systematicky v období od 6/2016 - 4/2017. Interval pre vstup do územia tvoril mesiac. Rekognoskáciou terénu sme overovali informácie z nadobudnutej a preštudovanej literatúry, pričom sme sa zameriavali aj na získanie nových poznatkov o záujmovom území pre spracovanie predmetných analýz. Zachytené morfogenetické a morfoskulptúrne javy sme interpretovali do mapy lokalizácie záujmového územia v mierke 1:15 000. Prednost’ou terénneho výskumu bolo aj vyhotovenie bohatej fotodokumentácie.

Pri spracovaní a interpretácii získaných informácií prostredníctvom predošlých metód sme použili metódu vysvetl'ujúceho opisu. Umožnila nám spracovanie nadobudnutých poznatkov z literatúry a terénneho výskumu do jednotlivých kapitol a podkapitol, pričom sa zachovala vysvetl'ujúca podstata dôležitých skutočností z odbornej literatúry.

Kvantitatívnemu spracovaniu nadobudnutých poznatkov predchádzala štatisticko-matematická metóda, ktorá nám umožnila efektívne vyhodnocovanie 
číselných údajov zo štatisticko-priestorovej analýzy vo forme tabuliek a grafov pre celkové sprehl'adnenie.

Prostredníctvom kartografickej metódy sme zhotovili mapy modelového územia $\mathrm{v}$ jednotnej mierke 1:15 $000 \mathrm{v}$ zmysle lokalizácie, morfometrických ukazovatel'ov reliéfu a priestorovej diferenciácie morfodynamických procesov. Adekvátnym bolo najmä využitie metódy bodových, líniových a areálových znakov, ktoré sme vytvárali v prostredí geografického informačného systému ArcGIS 10.2. Pre tvorbu mapy lokalizácie záujmového územia sme použili skladanú ortofotosnímku. Mapy morfometrických ukazovatel’ov reliéfu boli vygenerované z digitálneho modelu reliéfu (DMR). Ten bol vytvorený z pomerne presného bodového výškového pol’a vygenerovaného stereofotogrametrickými metódami firmou EUROSENSE s.r.o s presnost'ou $10 \mathrm{~m}$. Morfogenetické mapy vybraných procesov sme vypracovali prevažne na základe terénneho výskumu.

Celkový charakter a usporiadanie určovala systémová metóda, pomocou ktorej sme logicky usporiadali zozbierané spracované poznatky.

\section{Záujmové územie}

Malá Fatra je jadrové pohorie situované na severe Slovenska medzi Žilinskou a Turčianskou kotlinou. Na juhozápade hraničí so Strážovskými vrchmi a na severovýchode v údolí Oravy s Chočskými vrchmi. Strečnianskou tiesňavou je rozdelená na južnú - lúčanskú čast' a severnú - krivánsku čast' (Lukniš a kol., 1972).

Záujmové územie je súčast’ou Krivánskej časti Malej Fatry. Je súčast'ou Fatransko-tatranskej oblasti a geomorfologického celku Malá Fatra (Mazúr, Lukniš, 1980). Z hl’adiska územno-správneho členenia sa nachádza v Žilinskom kraji, okres Žilina, obec Terchová v závere doliny Vrátna (mapa 1), ktorá $\mathrm{v}$ tejto oblasti vytvára široké, silne sklonené vejáre $\left(30^{\circ}-40^{\circ}\right.$ a viac), často rozčlenené lavinóznymi ryhami zbiehajúcimi z ústredného hrebeňa (Mazúr, 1963). Zo severu zasahuje do územia čast' cestnej komunikácie a technickej infraštruktúry v podobe dolnej stanice kabínkovej lanovky $(740 \mathrm{~m} \mathrm{n}$. m.). Z tejto časti smerom na juhozápad územie lemuje takmer identicky trat' kabínkovej lanovky do sedla Snilov (1524 m n. m.). Odtial' južnou až juhovýchodnou hranicou záujmového územia prechádza samotný ústredný hrebeň vrátane príslušných vrcholov (Chleb, Hromové, Steny) a sediel (Snilovské sedlo, Sedlo v Stenách). Rozloha záujmového územia je $4020 \mathrm{~m}^{2}$.

$\mathrm{Na}$ geologickej stavbe územia sa podielajú najmä granitoidy, ílovité a slienité bridlice, slieňovce, ale i vápence guttensteinského typu a rádiolarity, pričom táto štruktúrno-litologická pestrost' má výrazný vplyv na reliéf územia, ktorý sa vyznačuje vel'kou pestrost'ou povrchových tvarov. Spôsobuje ich striedanie rozlične odolných hornín so svojráznym zvetrávaním. 
Mapa 1: Lokalizácia záujmového územia

Map 1: Location of interest area

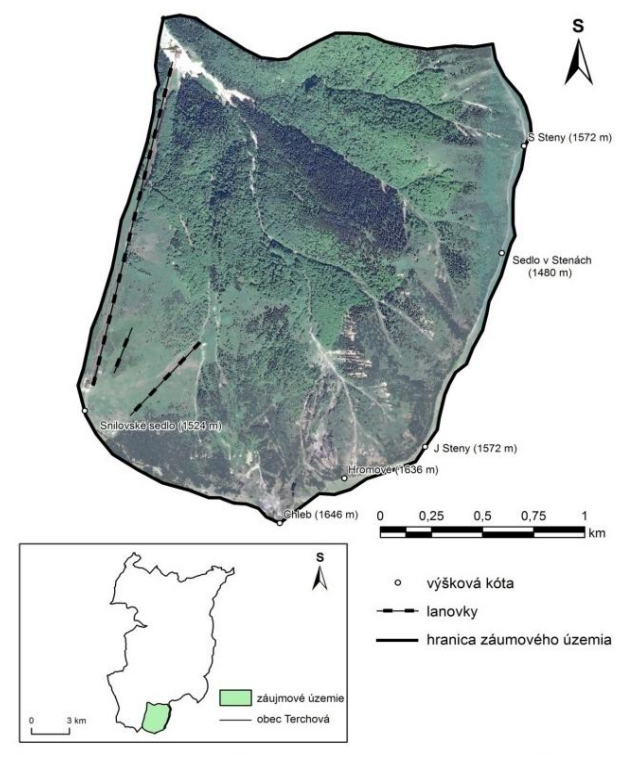

$\mathrm{Z}$ javov patriacich $\mathrm{k}$ l'adovcovej modelácii sa $\mathrm{v}$ literatúre uvádzajú malé kotly v severnej expozícii pod Chlebom. Prevažná čast' územia patrí do miernej chladnej oblasti s priemernou ročnou teplotou $3^{\circ}-6^{\circ}$, pričom celkový vývoj klimatických podmienok určuje hlavný hrebeň. Nad celou oblast'ou prevláda v priebehu roka cyklonálny charakter, kedy spadne $90 \%$ všetkých zrážok v roku. Územie spadá do povodia Váhu a odvodňuje ho sústava horských riečok a potokov, ktoré majú bystrinný charakter. Hlavným zdrojom vodnosti sú dažd’ové a snehové zrážky, a z časti aj podzemná voda. Pôdne typy tvoria litozem, ranker, rendzina, podzol, kambizem a v okolí potokov i fluvizem. Územie je prevažne zalesnené s výnimkou hrebeňov či lokalít ovplyvnených antropogénnym faktorom. Rastlinstvo možno diferencovat' podl'a sledu rozdielov výškovej a expozičnej klímy do týchto vegetačných stupňov: dubovo-smrekového, bukového, jedl'ovobukového, smrekovo-bukovo-jedl'ového, smrekového, kosodrevinového a alpínskeho. Stupne dopíňajú skalné spoločenstvá, vysokohorské lúky (hole), mokrade a prameniská. Zo živočíchov tu môžeme nájst' rôzne druhy hmyzu, cicavcov, vtákov a i. (Pagáč, Vološčuk, 1983).

Skúmané územie je súčast'ou Národného parku Malá Fatra, ako aj sústavy chránených území európskeho významu NATURA 2000 (Chránené vtáčie územie Malá Fatra). Čast' územia zasahuje aj do NPR Chleb, pričom v tejto oblasti platí 5. stupeň ochrany prírody. 
Dôvodom výberu záujmového územia bola skutočnost', že ide o najatraktívnejšiu čast' pohoria s rozmanitou fyzickogeografickou a morfometrickou charakteristikou, kde sa sústred'uje vel'ké množstvo reliéfotvorných procesov na relatívne malej ploche. Vedlajšiu úlohu zohrávala aj dobrá dopravná dostupnost', vd’aka čomu sme sa mohli častejšie venovat' terénnemu výskumu. Zaujal nás taktiež rastúci vplyv antropogénneho faktora na priestorovú štruktúru, či náchylnost' územia na murové prúdy a lavínovú aktivitu.

\section{Morfometrická analýza}

V rámci morfometrických parametrov sme analyzovali nadmorskú výšku, sklonitost', orientáciu, horizontálnu a vertikálnu krivost' reliéfu, z dôvodu úzkej nadväznosti na priebeh morfodynamických procesov.

Z hladiska nadmorskej výšky (mapa 2) je relatívny výškový rozdiel nášho záujmového územia $\pm 1000 \mathrm{~m}$. Z výsledkov priestorovo-štatistickej analýzy v prostredí GIS vyplýva, že najviac sú zastúpené výškové stupne $1400-1500 \mathrm{~m} \mathrm{n}$. m. (16,7 \%). Významné je ešte plošné zastúpenie výškového rozpätia 1300 - 1400 m n. m. (15,6\%) a 1200 - 1300 m n. m. (15,0 \%). Naopak najmenšiu plochu zaberá výškový stupeň $1600-1700 \mathrm{~m} \mathrm{n.} \mathrm{m.} \mathrm{(2,0 \% ).}$

Priemerná hodnota sklonitosti (mapa 3) vo zvolenom území je 29,9, pričom najväčší sklon územia je $52,6^{\circ}$ a najmenší $0,03^{\circ}$. Najväčšiu čast' zaberajú svahy so sklonom $30^{\circ}-40^{\circ}$ s plochou $1978 \mathrm{~m}^{2}(49,1 \%)$. Tie reprezentujú skalné steny či niektoré prudšie spády. Napokon najmenšiu čast' územia zaberajú svahy so sklonom menej ako $10^{\circ} \mathrm{s}$ výmerou $95,0 \mathrm{~m}^{2}(2,4 \%)$, ktoré tvoria sedlá, turistické chodníky a dolinovú čast'.

V skúmanom území zaberajú najväčšiu plochu svahy s orientáciou (graf 1) na severozápad o výmere $1315,5 \mathrm{~m}^{2}(32,7 \%)$, pričom značná je aj rozloha západne orientovaných svahov, ktorých výmera je $818,6 \mathrm{~m}^{2}(20,3 \%)$. Tretiu najväčšiu rozlohu majú severné svahy s plochou $757,1 \mathrm{~m}^{2}(18,8 \%)$. Najmenšiu čast' zaberajú juhovýchodné svahy s rozlohou len $14,0 \mathrm{~m}^{2}(0,3 \%)$.

Horizontálnu krivost' (mapa 4) reliéfu reprezentujú najviac lineárne tvary o výmere $2581,0 \mathrm{~m}^{2}(64,1 \%)$. Konkávne tvary, ktorými sú najmä doliny, žlaby a depresné formy zaberajú plochu 447,4 $\mathrm{m}^{2}$ (11,1\%). Konvexné tvary, pod ktorými rozumieme predovšetkým chrbty, hrebene a elevačné formy tvoria 999,6 $\mathrm{m}^{2}(24,8 \%)$.

Najväčšiu čast' v rámci vertikálnej krivosti (mapa 5) reliéfu predstavujú lineárne tvary s plochou $3109,6 \mathrm{~m}^{2}$, čo je až 77,2 \% z celkovej rozlohy územia. Konvexné tvary majú rozlohu $675,9 \mathrm{~m}^{2}(16,8 \%)$. Najmenej zastúpené sú konkávne tvary s plochou len $242,5 \mathrm{~m}^{2}(6,0 \%)$.

Pri niektorých reliéfotvorných procesoch sú dôležité aj d'alšie vlastnosti reliéfu ako je napríklad dížka svahov alebo vel'kost' príspevkovej plochy. Ide 
spravidla o procesy, ktorých činnost' úzko súvisí s týmito dvoma parametrami. Tieto procesy potom často sprevádza prítomnost' vel'kej masy materiálu z príspevkovej plochy, ktorá sa presúva po svahu s určitou dížkou, a v konečnom dôsledku určuje ich intenzitu aj rozsah vplyvu na d’alšiu formáciu povrchu.

Mapa 2: Výškové pomery záujmového územia

Map 2: The height ratios of interest area
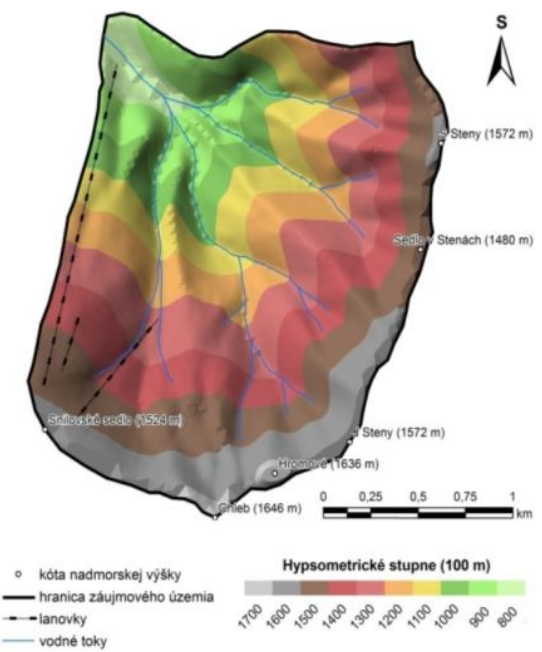

Mapa 3: Sklonitostné pomery záujmového územia

Map 2: The slope ratios of interest area

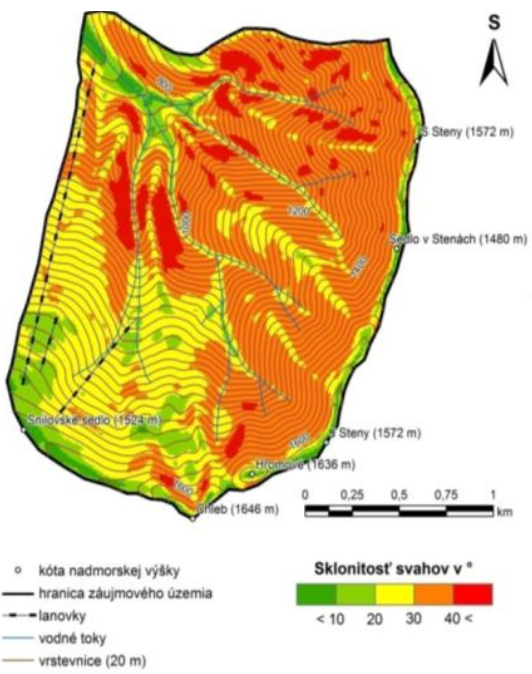

Graf 1: Podiel svahovej orientácie v záujmovom území $\left(\mathrm{v}^{\circ}\right)$

Graph 1: The proportion of slope orientation in interest area (in ${ }^{\circ}$ )

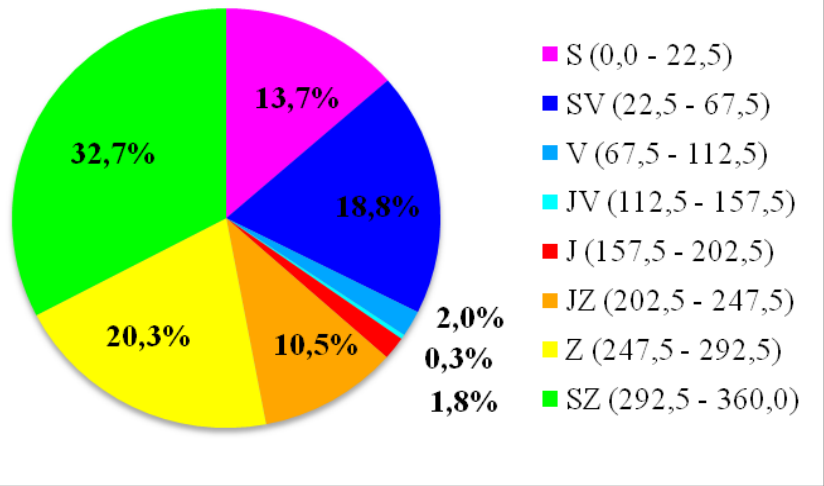


Mapa 4: Horizontálna krivost' záujmového územia

Map 4: The horizontal curvature of interest area
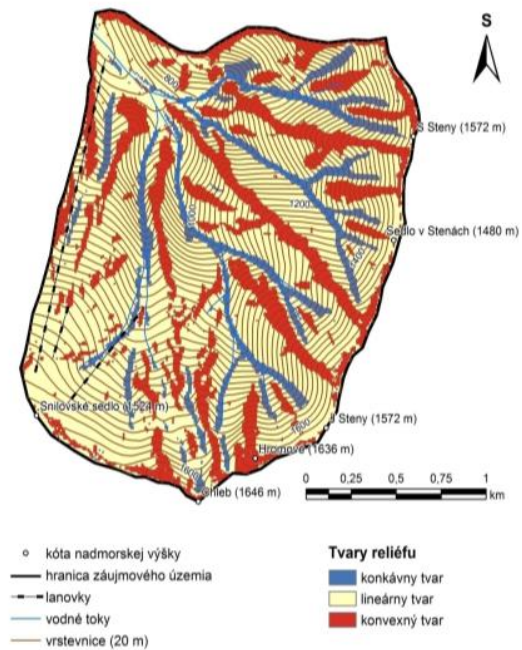

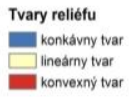

Mapa 5: Vertikálna krivost’ záujmového územia

Map 5: The vertical curvature

of interest area

\section{Morfodynamické procesy}
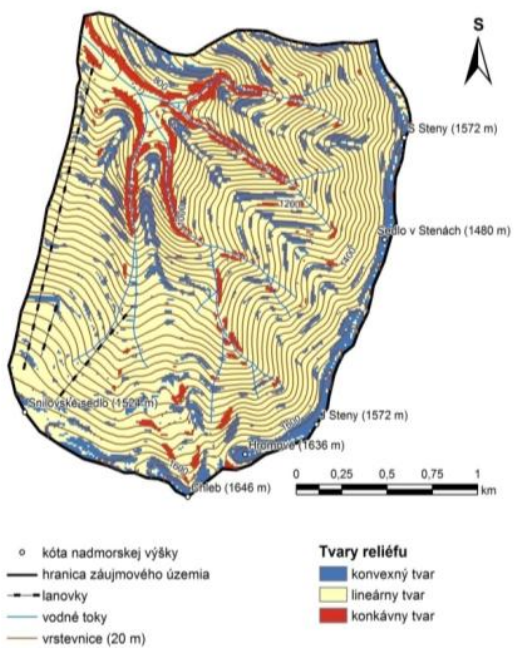

Medzi exogénne geomorfologické procesy odohrávajúce sa v skúmanom území patria vodné, gravitačné, vodnogravitačné, nivačnogravitačné, kryogravitačné, eolické, nivačné, kryogénne, zoogénne a antropogénne procesy, pričom $\mathrm{v}$ rámci nich ešte klasifikujeme samostatné podkategórie procesov. Intenzita týchto procesov závisí od morfometrických parametrov reliéfu, pričom materiál pre jednotlivé geomorfologické procesy poskytuje zvetrávanie (Horník, 1986).

Pre vodné procesy je typická aktívna stružková a výmol’ová erózia, ktorá sa vyskytuje v záujmovom území na exponovanom hlavnom hrebeni s mrazovým zvetrávaním skál, najmä však v depresných častiach svahov v zmysle žl’abov, sediel (Snilovské sedlo, Sedlo za Hromovým, Sedlo v Stenách), rýh a úšustov, kde sa sústred'uje vo zvýšenej miere povrchový odtok. Povrch menovaných foriem je z vel'kej časti bez akejkol'vek vegetácie, čo súvisí aj s tvrdením Barku (2005), že na intenzitu týchto procesov má vel'ký vplyv rastlinná pokrývka. V našom prípade jej čiastočná či úplná absencia. Priestor medzi hojným skeletom na povrchu vypíňa prevažne ílovitá jemnozem.

Vlastnost’ami gravitačných procesov v zmysle zliezania a plazenia sa vyznačuje najmä oblast' Chleba, ktorá je okrem pomalého zliezania, resp. plazenia 
drobnejších i masívnejších zvetraných sutín charakteristická aj zliezaním mačinového plášt’a pôdno-zvetralinovej pokrývky v kombinácii s kĺzaním mačinových bochníkov po rozrušení celistvosti pôdnej pokrývky vplyvom kombinácie nivačných, ale najmä kryogénnych procesov (obr. 1). Pre svahy postihnuté zliezaním je tu charakteristický lokálny sklon $30^{\circ}-50^{\circ}$, orientácia prevažne na sever a nadmorská výška $1500-1600 \mathrm{~m} \mathrm{n}$. m.

Rútenie menších kameňov sme identifikovali v oblastiach Chleba, resp. Chlebského kotla. Postihnuté svahy sa nachádzali vo výškovom rozpätí medzi 1550 - $1600 \mathrm{~m}$ n. m. Skalná strž (zlomisko) s deniveláciami do 30 metrov sa nachádzala na úpätí svahov.

Vodnogravitačná aktivita sa sústred'uje v severných podhrebeňových oblastiach. Najväčšie úšustové polia sú sústredené v oblasti Hromového a Stien na slienitých vápencoch a bridliciach so sklonom $30^{\circ}-50^{\circ}$. Majú asymetrický tvar, pričom charakteristická je pre ne široká základňa s obnaženým skalným podložím, ktorá sa postupne zmenšuje, resp. pretvára do lievikovitého útvaru smerom k dolinovým žl'abom. Úšusty však postihujú i karbonátovú čast' nášho záujmového územia, ktorú tvorí oblast' Chleba.

Dynamikou murových prúdov sa vyznačovali aj hlinito-kamenité prúdy (mury) vo Vrátnej doline, spolu so sprievodnými zosuvmi, resp. úšustami, ktoré vznikli 21.7.2014 v dôsledku zrážkových anomálií (mapa 6). Na slienitých sedimentoch mráznického súvrstvia sú vyvinuté hlinito-kamenité až hlinité delúviá, kde práve $\mathrm{v}$ týchto deluviálnych sedimentoch sa pod hrebeňom zhruba vo výške $1600-1500 \mathrm{~m} \mathrm{n}$. m. aktivovali hlinito-kamenité prúdy hrúbky 1 až $2 \mathrm{~m}$. Svahové pohyby po planárnej šmykovej ploche tu boli podmienené priaznivým sklonom vrstevnatosti/bridličnatosti $\left(15^{\circ} / 11^{\circ}\right.$ až $\left.16^{\circ}\right)$. V odlučných častiach týchto zosuvov nevel'kej hrúbky sa odtrhli pomerne malé, ale početné ,platne“ zosuvného materiálu, ktoré sa spravidla pohybovali preferenčne lavínovými žlabmi, často krát po vegetačnom pokryve. Väčšina prúdov erodovala dolinky až na skalný podklad Liščák a kol., 2014).

Nivačnogravitačné procesy $\mathrm{v}$ zmysle lavínovej aktivity najčastejšie pôsobia na svahoch Chleba, Hromového a Stien, kde dochádza aj k najväčšiemu poškodzovaniu vegetačnej a pôdnej pokrývky v súčasnosti. Malá Fatra je podl’a Žiaka (2016) z hl'adiska lavínového ohrozenia pohorie, ktoré svojim charakterom vytvára predpoklady vzniku lavín rozsiahlych rozmerov. $Z$ analýzy sklonitostných pomerov záujmového územia vyplýva, že až $4 / 5$ lavínových dráh sa nachádzajú na svahoch so sklonom $30^{\circ}-40^{\circ}$. Zriedkavo sa však lavíny vyskytujú aj v okolí Snilovského sedla, kde obrusujú hladké svahy lyžiarského vleku Oštiepková mulda. Transportnú zónu pre lavíny poskytujú dolinové žl’aby. Akumulácia materiálu sa sústred'uje v samotných žl’aboch, prípadne v ústiach (mapa 7).

Kryogravitačné procesy, pod ktorými Midriak (1983) rozumie soliflukčné procesy, a pre ktoré sú typické tvary amorfnej soliflukcie lemované vegetačnými obrubami v podobe soliflukčných prúdov, resp. nátekov, sa vyskytujú na severnom 
až severozápadnom svahu Chleba. Materiál prúdov tvorí ílovito-hlinitá jemnozem s primiešanými blokmi kameňov. Lokálny sklon sa tu pohybuje na úrovni medzi $30^{\circ}-40^{\circ}$. V dôsledku toho sa na týchto svahoch vytvárajú terasoidné polmesiacovité tvary zvané girlandy, ktoré sa nachádzajú vo výške nad $1500 \mathrm{~m} \mathrm{n}$. m., pričom najtypickejšie vyvinuté sú na severozápadnom svahu Chleba.

Deštrukčným účinkom eolických procesov (obr. 2) v dôsledku pôsobenia vetra sú najviac vystavené vrcholy (Chleb, Hromové, Steny - južný vrchol, Steny severný vrchol, Poludňový Grún̆), sedlá (Snilovské sedlo, Sedlo za Hromovým a Sedlo v Stenách) a hlavný hrebeň, pričom najmä v sedlách dochádza k dýzovému efektu a zvyšovaniu rýchlosti vetra (Krusiec, 1996). Najnovšie sú eolickou eróziou postihnuté aj obnažené, mohutné úšustové polia, ktoré sú rozstrúsené na svahoch pod severnou stranou hlavného hrebeňa (mapa 8).

Obr. 1: Zliezanie mačinového plášt’a v kombinácii s kízaním mačinových bochníkov

Figure 1: Creeping of the cloak in combination with the sliding of the turf loaves

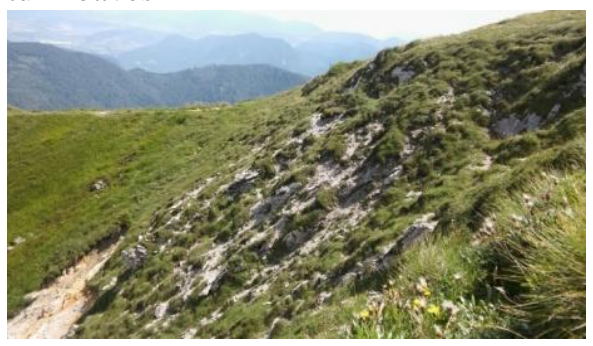

Obr. 2: Okraj turistického chodníka ned'aleko vrchu Chleb postihnutý eolickou eróziou

Figure 2: The edge of the tourist trail near the peak of Chleb affected by the eolic erosion

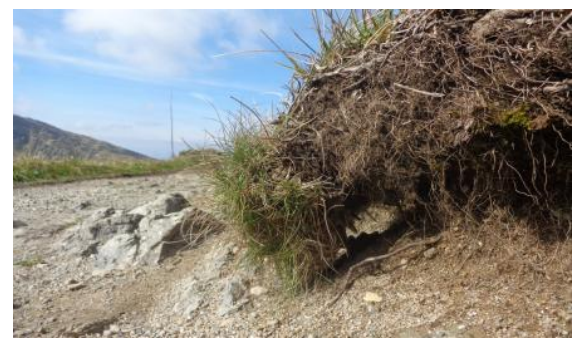

Počas terénneho výskumu sme pozorovali nivačné procesy najmä v rámci konkávnych tvarov reliéfu. Išlo o žl'aby vyhíbené eróznou činnost’ou lavín a vody, ktoré zbiehali z hlavného hrebeňa. Tienistá a chladná mikroklíma, ktorá sa v týchto žl'aboch udržuje kvôli charakteristickému zakriveniu, ako aj prevažne severná až severozápadná expozícia svahov, poskytujú vhodné podmienky pre pretrvávanie snehových polí. Rovnako priaznivé sú aj sklonitostné pomery, kde lokálny sklon svahov nepresahuje $30^{\circ}$ a umožňuje pomalé nivačné zahlbovanie. Niváciou sú postihnuté aj záveterné svahy ústredného hrebeňa. Pri pozorovaní sme si zároveň všimli, že snehové polia sa tu udržujú v nadmorskej výške $1200-1700 \mathrm{~m}$.

V rámci záujmového územia pôsobia kryogénne (regelačné) procesy v zmysle ihlicovitého l'adu na všetkých obnažených povrchoch v podobe hladkých povrchov turistických chodníkov (obr. 3), ako aj na obnažených poliach 
vzniknutých po mohutných pôdno-zvetralinových stržiach situovaných najmä v severných podhrebeňových oblastiach, kde spôsobujú aj vydúvanie súvislej vrstvy jemnozeme (obr. 3). Ihlicovitý l'ad na týchto miestach svojou silou vyzdvihuje aj niektoré menšie skaly. Špecifickým bolo aj zistenie, že pipkrake svojou morfogenéznou činnost'ou v tejto oblasti má za následok nielen oddelenie jemnozeme a menších skál od povrchu, ale aj vyzdvihnutie odumretých častí trávobylinnej vegetácie, machov a ihličia (mapa 9).

Obr. 3: Ihlicovitý pôdny l’ad - pipkrake vyzdvihujúci jemnozem na povrchu hladkého turistického chodníka

Figure 3: Needle ice - pipkrake picking up the clay on the surface of a uncover hiking trail

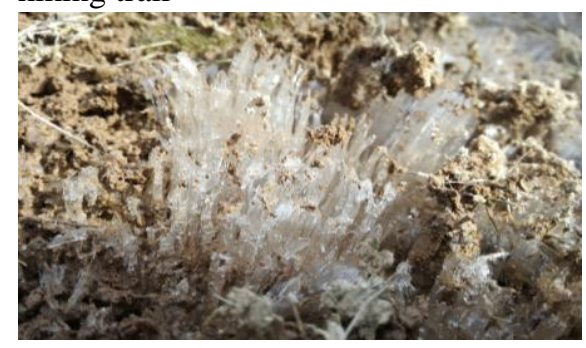

Obr. 4: Hustá siet' prtí so šírkou terasiek $1-2$ dm vytvorená zdieraním mačiny kopytami zvierat

Figure 4: Many of narrow trails with a spread $1-2 \mathrm{dm}$ created by hoofs of animals

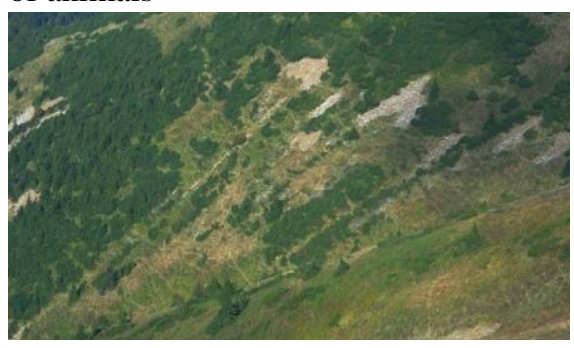

Z hl'adiska zoogénnych procesov sa na prudších svahoch vytvorila vplyvom zdierania mačiny a mechanickej deštrukcie pôdy kopytami zvierat hustá siet' prtí so šírkou terasiek do $1-2 \mathrm{dm}$ (obr. 4). Tieto prte sú zväčša situované v smere vrstevníc, pričom obnažujú pôdu najprv vo forme malých jamiek alebo vyhĺbenín, neskôr však súvisle v pásoch i vo forme eróznych nátrží. Stávajú sa tak ohniskami d’alšej deštrukcie eróznymi, ale najmä kryogénnymi procesmi. Hustú siet' prtí spôsobenú najmä pastvou druhov Cervus elaphus, Capreolus capreolus, ale i Sus scrofa možno v území pozorovat' vo výške $1200-1400$ m n. m. na severných až severozápadných svahoch pod Chlebom, Hromovým a Stenami, kde využívajú tieto živočíchy horské lúky pre svoju obživu. Podzemné dutiny $\mathrm{v}$ zmysle nôr a brlohov najmä drobných cicavcov sú zväšša roztrúsené v rámci celého záujmového územia nerovnomerne.

Deštrukcia pôdy podmienená antropogénnou aktivitou vzniká v našom záujmovom území najmä na strmších úsekoch, zákrutách, odbočkách a križovatkách chodníkov či na ich spádnicových skratkách. K tomu pristupuje na turistických chodníkoch a cestách ako významný faktor i zošl’apávanie ich okrajov, ktoré je okrem strmých úsekov chodníkov zjavné prakticky v celej oblasti hlavného hrebeňa a chrbtov, kde sú umiestnené hlavné trasy značkovaných 
turistických ciest. Typickým následným javom je aj niekol'konásobné prekladanie chodníka po jeho čiastočnej deformácii a najmä vyhíbení vplyvom vertikálnej erózie, čo vedie bez použitia účinných technických pôdoochraných opatrení k d’alšej permanentnej deštrukcii chodníkov, resp. celého svahu či chrbta.

$\mathrm{Z}$ d'alších negatívnych antropogénnych vplyvov $\mathrm{v}$ súvislosti s turistikou, resp. rekreáciou treba spomenút' samotné budovanie výt’ahov či lyžiarskych vlekov, ktoré sú súčast'ou aj nášho záujmového územia. Severozápadným okrajom predmetného územia sa tiahne kabínková lanovka (výt'ah), ktorej dolná stanica leží v ústí svahov Vrátnej doliny. Podl'a Midriaka (1983) sa pri výstavbe týchto zariadení na mnohých miestach odstraňuje lesná i nelesná vegetácia, a tým sa koncentruje a urýchl'uje povrchový odtok, čo napokon nepriamo spôsobuje deštrukciu pôdy zbavenej ochranného vegetačného krytu $\mathrm{v}$ polohách s intenzívnymi zrážkami, vyvolávajúcimi erózne procesy.

$\mathrm{Z}$ dôvodu obmedzenej kapacity obsahu článku však uvádzame len niektoré grafické interpretácie priestorovej diferenciácie reliéfotvorných procesov v podobe mapových výstupov (vid'. mapa $6,7,8,9$ ).

Mapa 6: Priestorová diferenciácia vodnogravitačných procesov Map 6: Spatial differentiation of water-hillslope processes

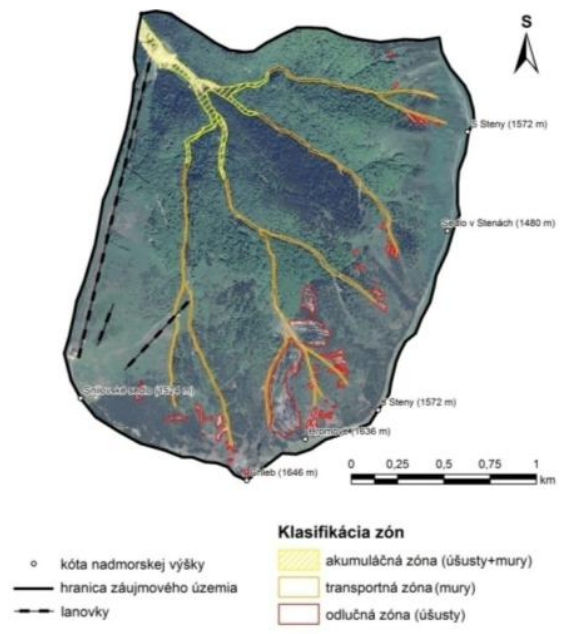

Mapa 7: Priestorová diferenciácia nivačnogravitačných procesov Map 7: Spatial differentiation of nivation-hillslope processes

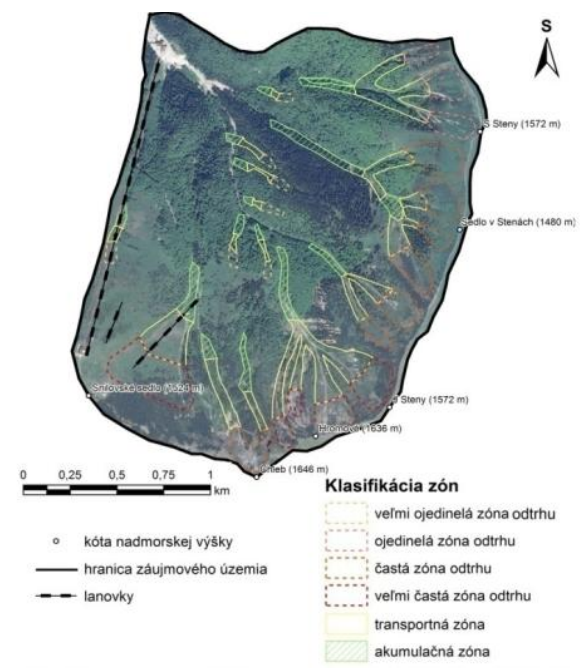


Mapa 8: Priestorová diferenciácia eolických procesov Map 8: Spatial differentiation of eolic processes
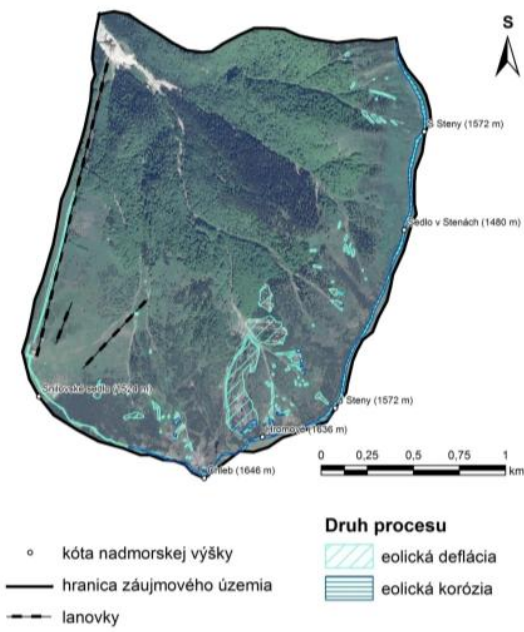

Mapa 9: Priestorová diferenciácia kryogénnych procesov

Map 9: Spatial differentiation

of cryogenic processes
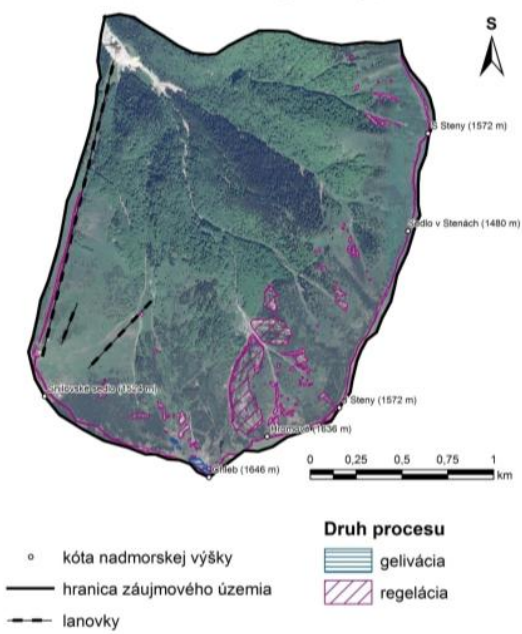

\section{Záver}

Prostredníctvom vybraných metód a postupov sme sa dopracovali k získaniu komplexných informácií o reliéfe skúmaného územia, o jeho vlastnostiach a reliéfotvorných procesoch typických pre toto územie. Dospeli sme k záveru, že fyzickogeografické pomery tvoria základ pre pôsobenie pôdnodeštrukčných javov, a na vážnosti naberajú v súčinnosti s morfometrickými parametrami reliéfu. $\mathrm{V}$ dôsledku tohto vzt’ahu majú výrazný vplyv na povrch záujmového územia $\mathrm{v}$ podobe morfodynamických procesov formujúcich miestny povrch, pričom ovplyvňujú aj ich priestorovú diferenciáciu v krajine (Hreško et al., 2003, 2008, Boltižiar, 2001, Kapusta et al., 2018).

$\mathrm{Z}$ výsledkov terénneho výskumu vyplýva, že pri vodných procesoch hrá v rámci vlastností reliéfu dôležitú úlohu najmä sklon svahov (cca $\left.10^{\circ}-40^{\circ}\right)$ a zakrivenie povrchu (najmä konkáv). Pre gravitačné procesy je kl'účový skon svahov (cca $20^{\circ}-40^{\circ}$ ), ale i nadmorská výška (nad $1200 \mathrm{~m} \quad \mathrm{n} . \quad \mathrm{m}$.). $\mathrm{Na}$ vodnogravitačné a nivačnogravitačné procesy najväčšmi vplýva skon svahov (najviac $30^{\circ}-40^{\circ}$ ) a expozícia (najmä $\mathrm{J}, \mathrm{JV}, \mathrm{Z}, \mathrm{SZ}$ ) pričom $\mathrm{z}$ hl'adiska kryogravitačných procesov je to okrem sklonitosti aj najmorská výška (nad $1200 \mathrm{~m}$ n. m.). Eolické procesy sú ovplyvňované expozíciou reliéfu 
(náveterná a záveterná strana). $\mathrm{V}$ rámci nivačných procesov sa spája kombinácia nadmorskej výšky (nad $1000 \mathrm{~m} \mathrm{n}$. m.), sklonistosti $\left(10^{\circ}-20^{\circ}\right)$, expozície (S, SV, SZ) a zakrivenia reliéfu (konkáv). Pre kryogénne procesy je dôležitá expozícia (S, SV) a zakrivenie svahov (viac konkáv), a z časti aj sklonitost' a nadmorská výška (nad $1200 \mathrm{~m} \mathrm{n}$. m.). Dominantným parametrom v súvislosti so zoogénnymi procesmi je sklon svahov (zväčša neprekračuje $40^{\circ}$ ) a expozícia ( $v$ závislosti od druhu), pričom v rámci antropogénnych procesov sú rozhodujúcimi vlastnot'ami reliéfu sklonitost' ( $\mathrm{v}$ závislosti od druhu), expozícia ( $\mathrm{v}$ závislosti od druhu) i zakrivenia (konkáv, konvex, ale aj svahy).

Výsledky práce možno využit' pre d’alšie praktické a poznávacie ciele ako aj vo vyučovacom procese. Nadobudnuté poznatky môžu taktiež poslúžit' ako kvalitný podklad pre zefektívnenie ochrany prírody nielen na území Národného parku Malá Fatra, ale i pre d’alšie ochranné pásma v rámci územia celej krajiny.

\section{Literatúra}

BARKA, I. 2005. Niektoré metodické postupy pri mapovaní vybraných geomorfologických procesov. Bratislava: Univerzita Komenského v Bratislave, 2005. 108 s. ISBN 80-223- 2148-6.

BOLTIŽIAR, M. 2001. Evaluation of vulnerability of high-mountain landscape on example Velická valley in the High Tatras Mts. In Ekológia (Bratislava). vol. 20, Supplement 4, pp. 101-109.

HORNÍK, S. 1986. Fyzická geografia II. Praha: Státni pedagogický nakladatelství, n. p., 1986. $320 \mathrm{~s}$.

HREŠKO, J. - BOLTIŽIAR, M. 2001. The influence of the morphodynamic processes to landscape structure in the high mountains (Tatra Mts.). In Ekológia (Bratislava). vol. 20, Supplement 3, pp. 141-148.

HREŠKO, J. - BOLTIŽIAR, M. - BUGÁR, G. 2003. Spatial structures of geomorphic processes in high-mountain landscape of the Belianske Tatry Mts. In Ekológia (Bratislava). vol. 22, Supplement 3, pp. 341-348.

HREŠKO, J. - BUGÁR, G. - BOLTIŽIAR, M. - KOHÚT, F. 2008. Dynamics of recent geomorphic processes in alpine zone of the Tatra Mts. In Geographia Polonica. vol. 81, no. 1, pp. 53-65.

KAPUSTA, J. - PETROVIČ, F. - HREŠKO, J. 2018. Monitoring open water area changes in a small tarn using historical orthophotomaps and a historical bathymetric map: a case study of the Litworowy Staw lake, the High Tatras. In Journal Of Mountain Science. vol. 15, no. 10, pp. 2089-2102.

KRCHO, J. 1990. Morfometrická analýza a digitálne modely georeliéfu. Bratislava: Veda, 1990. 426 s. ISBN 80-224-0018-1.

KRUSIEC, M. 1996. Wplyw ruchu turystycznego na przeksztacanie rzeby Tatr Zachodnich. In Czasopismo geograficzne. 1996, vol. 67, pp. 3-4.

LACIKA, J. 1997. Geomorfológia. Zvolen: FEE TUZVO, 1997. 172 s. 
LIŠČÁK, P. a kol. 2014. Informatívna správa z geologického prieskumu - Hlinitokamenité prúdy vo Vrátnej. [online]. Bratislava: ŠGúDŠ, 2014. 7 s. [cit. 2018-09-08]. Dostupné na internete: https://www.geology.sk/new/sites/default/files/media/Aktuality/Vratna_dolina_ 2014/Vratna_informat\%C3\%ADvna_sprava_web.pdf.

LUKNIŠ, M. a kol. 1972. Slovensko II. - Príroda. Bratislava: Obzor, 1972. 920 s. MAZÚR, E. 1963. Žilinská kotlina a pril'ahlé pohoria (Geomorfológia a kvartér). Bratislava: SAV, 1963. $188 \mathrm{~s}$.

MAZÚR, E. - LUKNIŠ, M. 1980. Regionálne geomorfologické členenie Slovenskej republiky. [online]. [cit. 2018-09-09]. Dostupné na internete: http://mapserver.geology.sk/tmapy/.

MIDRIAK, R. 1983. Morfogenéza povrchu vysokých pohorí. Bratislava: Veda, 1983. $516 \mathrm{~s}$.

MINÁR, J. - MACHOVÁ, Z. 2010. Učebné texty z geomorfológie. [online]. Bratislava: Univerzita Komenského v Bratislave, Prírodovedecká fakulta, 2010. [cit. 2018-09-09]. Dostupné na internete: http://fns.uniba.sk/Geomorfoskripta/.

PAGÁČ, J. - VOLOŠČUK, I. 1983. Malá Fatra - Chránená krajinná oblast'. 1. vyd. Bratislava : Príroda, 1983. $356 \mathrm{~s}$.

ŽIAK, M. 2018. Aká je Malá Fatra z hl’adiska lavínovej ohrozenosti. [online]. [cit. 2018-10-01]. Dostupné na internete: http://avalanche.sk/aka-je-mala-fatraz-hladiska-lavinovej-ohrozenosti/

\section{MORPHOMETRIC ANALYSIS AND MORPHODYNAMIC PROCESSES IN THE SELECTED PART OF MALÁ FATRA MTS.}

\section{Summary}

In terms of altitude and the results of spatial-statistical analysis in the GIS, it is clear that the most represented height level in the interest are is between $1400-1500 \mathrm{~m} \mathrm{n}$. m. $(16.7 \%)$. The average slope value is $29.9^{\circ}$ with the largest slope of the area $52,6^{\circ}$ and the lowest $0,03^{\circ}$. Most of them form hillsides with a slope of $30^{\circ}-40^{\circ}$, with an area of $1978 \mathrm{~m}^{2}(49.1 \%)$. In terms of orientation, the largest area of northwestern slopes is formed by a surface area of $1315.5 \mathrm{~m}^{2}$ $(32.7 \%)$. Horizontal curvature of the relief represents the most linear shapes with an area of $2581.0 \mathrm{~m}^{2}(64.1 \%)$. The largest part of the vertical curvature of the relief is represented by linear shapes with an area of $3109.6 \mathrm{~m}^{2}$, which is up to $77.2 \%$ of the total area.

The water processes are situated in the area of interest near the main ridge, especially in the depressions of slopes, like gutters, saddles (Snilovské saddle, Saddle behind Hromové, Saddle in Steny), grooves and ravines, where they are concentrated to an increased level of surface runoff. The hillslope processes, like creeping etc., is characterized in particular by the area of Chleb, 
which in part also affects the rock falls. Water-hillslope processes are concentrated in the area below the main ridge. The largest damaged fields are situated near the Hromové and Steny area on limestones and slates with a slope of $30^{\circ}-50^{\circ}$. Nivation-hillslope processes, like avalanche activity, are most often exist on the hillsides of Chleb, Hromové and Steny, where the vegetation and soil cover is the most damaged at present. Cryogenic processes for which is typical amorphous solifluction are lined with vegetation rims in the form of solifluction streams, occur on the north and the northwest hillsides of the Chleb. The local slope is here between $30^{\circ}-40^{\circ}$. The destructive effects of eolic processes due to the wind are the most exposed peaks (Chleb, Hromové, Steny - southern peak, Steny - northern peak, Poludňový Grúň), saddles (Snilovské saddle, Saddle behind Hromové, Saddle in Steny) and the main ridge. During research, we are observed the processes of nivation especially within concave relief shapes. By the nivation is affected the main ridge also, where the local slope of the hillsides does not exceed $30^{\circ}$. In the interest area, cryogenic processes, like needle-ice, are occur on all exposed surfaces in the form of smooth surfaces of hiking trails as well as in uncovered fields. From the point of view of zoological processes, the steep slopes are formed by the mechanical destruction by the hoofs of animals, where arises a dense system of ways with a terraces width of 1 to $2 \mathrm{dm}$. A dense system due to grazing can be observe in the area between 1200 and $1400 \mathrm{~m}$. m. on the north to northwest slopes below Chleb, Hromové and Steny. Degradation of soil due to anthropogenic activity arises in our area of interest especially on steep sections, bends, branches and crossroads of walkways or their shortcuts.

The intensity of these processes depends on the morphometric parameters of the relief, while the material for the individual geomorphological processes provides the weathering.

\section{Bc. Veronika Máliková}

Katedra geografie a regionálneho rozvoja

Fakulta prírodných vied

Univerzita Konštantína Filozofa v Nitre

Trieda A. Hlinku 1, 94949 Nitra

E-mail: veronika.malikova@ student.ukf.sk 